\title{
GROWTH OF NILE TILAPIA Oreochromis niloticus FED WITH DIFFERENT LEVELS OF ALCOHOL YEAST
}

\author{
MEDRI, V., PEREIRA, G. V. ${ }^{2}$ and LEONHARDT, J. H. ${ }^{3}$ \\ ${ }^{1}$ Departamento de Matemática Aplicada, Universidade Estadual de Londrina, Campus Universitário, \\ CEP 86051-990, Londrina, PR, Brazil \\ ${ }^{2}$ Departamento de Química, Universidade Estadual de Londrina, Campus Universitário, CEP 86051-990, \\ Londrina, PR, Brazil \\ ${ }^{3}$ Departamento de Biologia Animal e Vegetal, Universidade Estadual de Londrina, Campus Universitário, \\ CEP 86051-990, Londrina, PR, Brazil \\ Correspondence to: Vandir Medri, Rua Santos, 267, apto. 502, Centro, CEP 86020-020, Londrina, PR, \\ Brazil, e-mail: vandir@npd.uel.br \\ Received October 21, 1998 - Accepted March 1, 1999 - Distributed February 28, 2000
}

(With 1 figure)

\begin{abstract}
Two hundred and forty 45-day-old fingerlings of Nile tilapia (Oreochromis niloticus), sexually reverted with an initial average weight of $1.25 \pm 0.14 \mathrm{~g}$, distributed in a totally casualized delineation, during 330 days. The effect of the substitution of $10 \%, 20 \%$ and $30 \%$ of the ration by distillery yeast (Saccharomiyces cerevisae) in balanced experimental rations on the development in the breeding of tilapias did not show a harmful effect up to the maximum tested level of $30 \%$, showing that the choice of the yeast in the ration for these fishes depends on the availability and occasional cost. The yeast provides fish with good resistance to unfavorable environmental conditions, which could be verified since there were no statistical differences among the treatments with different levels of yeast and the witness. The long growth rate in terms of length and weight can be attributed to the little available space for each specimen, not obeying the limit of populational density, as well as reduction of food ingestion, which coincide with the winter season, above of the absence of natural feeding.
\end{abstract}

Key words: yeast, Oreochromis niloticus, ration, tilapia.

\section{RESUMO}

\section{Crescimento das tilápias do Nilo Oreochromis niloticus alimentadas com diferentes níveis de levedura alcooleira}

Foram utilizados 240 alevinos de tilápia do Nilo (Oreochromis niloticus), com 45 dias, sexualmente revertidos com peso médio inicial de $1,25 \pm 0,14 \mathrm{~g}$, distribuídos em um delineamento inteiramente casualizado, durante 330 dias. O desempenho da substituição de 10\%, 20\% e 30\% da ração por levedura de destilaria (Saccharomyces cerevisiae) em rações experimentais balanceadas sobre o desenvolvimento na criação de tilápia do Nilo não mostrou efeito prejudicial até o nível máximo testado de $30 \%$, indicando que a escolha do nível de levedura na ração para estes peixes depende de sua disponibilidade e custo ocasional. A levedura proporcionou aos peixes boa resistência às condições ambientais desfavoráveis, o que foi constatado pela não diferença estatística entre os tratamentos com diferentes níveis de levedura e o controle. O baixo índice de crescimento em comprimento e peso pode ser atribuído ao pouco espaço disponível por exemplar, não obedecendo o limite de densidade populacional, e uma diminuição da ingestão de alimentos coincidindo com o período de inverno, além da ausência de alimentação natural.

Palavras-chave: levedura, Oreochromis niloticus, ração, tilápias. 


\section{INTRODUCTION}

Yeast is a worth product, adequately balanced, withdrawn from the process of alcoholic fermentation, and is an important alternative of protein on formulation of animal ration, so that high levels of protein, carbohydrates, lipids, etereo extract, vitamins and minerals are obtained (Mattos, 1984; Medri, 1997).

The Brazilian population eats deficiently in terms of quantity and quality, therefore there is necessity to develop new ways of using the industrial residues, transforming them into protein when used in the animals diet, besides the reduction on the costs and the minimization of the pollutant force of these residues in rivers and lakes (Neto et al., 1988).

Unicellular protein or yeast could be used as proteic supplement in animal rations as well as in enrichment of school lunch, on account to the low rate of protein contained on the diet of most part of the population (Carneiro, 1971).

It is necessary effort to convince the industrials of the quality of a sugarcane subproduct, such as the yeast withdrawn from the fermentation process. Yeast is a worth product, but its importance is not recognized in the marked, so the industries are not stimulated to produce it.

The improving necessity in quality and quantity of food, bring the industrials and scientists to work harder on the progress of the production, through advanced methods that maximize the efficiency when using natural, human, technological and economical resources but not degrading the environment.

Tilapias present excellent characteristics, such as rusticity, fast increase of weight and ability to make use of agroindustrial residues such as yeast, besides the possibility of assimilate efficiently carbohydrates from the vegetable ingredients of rations.

Young tilapia eat mainly zooplancton and phitoplancton; while the adults, accept a variety of artificial food, vegetables, larvae and insects (Castagnolli, 1992; Wu et al., 1995).

The objective of this article is to show through statistic the inclusion of $10 \%, 20 \%$ and $30 \%$ of distillery yeast in experimental rations and the relative growth of the fishes in weight and length.

\section{MATERIAL AND METHODS}

\section{Experimental conditions}

Two hundred and forty fingerlings of Nile tilapia (Oreochromis niloticus), ceded by the Fish Breeding Station of the Animal and Vegetal Department of Biology Science Center of the Universidade Estadual de Londrina. The initial average weight and length of the fingerlings were respectively $1.25 \pm 0.14 \mathrm{~g}$ and $3.84 \pm 0.17 \mathrm{~cm}$. The fishes were reverted by the supply of rations with $60 \mathrm{mg} / \mathrm{Kg}$ of diet of the male hormone $17 \alpha$ metiltestosterone, during a period of 30 days.

A computational program was utilized to elaborate the ration BRUN10 with the needs of the mentioned species. The four isoproteic $(28 \% \mathrm{~PB})$ and isocaloric balanced rations $(2,933 \mathrm{Kcal} / \mathrm{kg})$ with $0 \%$ (standard group), $10 \%, 20 \%$ and $30 \%$ (tested groups) of yeast from alcoholic distillery exceeding (Table 1).

Each of the rations treatment named $(\mathrm{T})$ was given to three groups of fishes (triplicate). The fingerlings were daily fed according to Wilson (1991).

The fingerlings were randomly distributed in 12 groups of 20 individuals, each group was placed in an amianthus box with capacity for 500 liters, with continuos aeration and water exchange. They were supplied with water from a semi-artesian well, with discharge of 6 liters/second/hectare and placed in a closed environment.

The box were siphoned weekly to remove residues and algae deposited on the bottom and on the walls. The fishes were daily observed in case of any uncommon behavior, morphological variation and death. The experimental period was 330 days $(15 / 03 / 95$ to $15 / 02 / 96)$. Using a paquimeter and a balance of precision, the total weight (Wt), in grams, and the total length of the fishes $(\mathrm{Lt})$, in centimeters, were monthly measured.

The water temperature was checked every day with a mercury thermometer. Monthly, the alkalinity was measured through the addition method, the dissolved oxygen through Winkler method, ammonia through photometer method of Berthelot, nitrite through Griess-Hosvay, total phosphorus and dissolvable phosphorus through Murphy and $\mathrm{pH}$ through potentiometer. The methodology used to test these parameters was according to Lind (1979) and Standard Methods (1980). 
TABLE 1

Composition of the experimental rations for the Nile tilapia.

\begin{tabular}{|c|c|c|c|c|}
\hline Ingredients (\%) & Standard $\left(T_{1}\right)$ & Test $\left(\mathbf{T}_{2}\right)$ & Test $\left(\mathrm{T}_{3}\right)$ & Test $\left(\mathrm{T}_{4}\right)$ \\
\hline Yeast & 0.00 & 10.00 & 20.00 & 30.00 \\
\hline Ration & 100.00 & 90.00 & 80.00 & 70.00 \\
\hline Total & 100.00 & 100.00 & 100.00 & 100.00 \\
\hline \multicolumn{5}{|l|}{ Ration formulation (\%) } \\
\hline Yeast & 0.00 & 10.00 & 20.00 & 30.00 \\
\hline Fish flour & 27.00 & 25.00 & 23.00 & 15.00 \\
\hline Wheat flour & 13.00 & 15.00 & 17.00 & 15.00 \\
\hline Crushed maize & 47.30 & 41.01 & 35.31 & 30.11 \\
\hline Soybean flour & 11.05 & 7.75 & 3.99 & 9.89 \\
\hline Vegetable oil & 1.65 & 1.24 & 0.70 & --- \\
\hline Total & 100.00 & 100.00 & 100.00 & 100.00 \\
\hline \multicolumn{5}{|l|}{ Ration nutrients (\%) } \\
\hline Dry matter & 87.86 & 87.86 & 88.90 & 89.24 \\
\hline Crude protein & 28.00 & 28.00 & 28.00 & 28.00 \\
\hline Methabolicable energy $(\mathrm{kcal} / \mathrm{kg})$ & 2933.00 & 2933.00 & 2933.00 & 2933.00 \\
\hline Calcium $(\mathrm{Ca})$ & 1.54 & 1.55 & 1.34 & 0.97 \\
\hline Phosphorus (P) & 1.15 & 1.14 & 1.13 & 0.97 \\
\hline
\end{tabular}

The finality of this control is to determinate the quality and quantity of water, which is essential on the interpretation of the results of this research. Thus, it is possible to attribute any dispersion on the fish growth only to the variation of ration applied.

\section{Quantitative analysis}

The development of the tilapias related to the different treatments was analyzed through the quantitative analysis of the relation total weight/ total length (Santos, 1978), total biomass, efficiency index (Swingle, 1961; Ivlev, 1966), increment in length and weight, increase of absolute weight and total relative weight, graphical expression of growth in length and weight (Ricker, 1979), graphical expressions of biomass and production (Webb, 1978; Ricker, 1979).

\section{RESULTS AND DISCUSSION}

\section{Tilapias growth}

The results for the average total length and weight of the standard group $\left(\mathrm{T}_{1}\right)$ and the tested groups $\left(\mathrm{T}_{2}, \mathrm{~T}_{3}\right.$ and $\left.\mathrm{T}_{4}\right)$ of tilapias are presented on Table 2 .
The low index of growth, length and weight (Table 2 and Fig. 1) in the amianthus box can be associated to the absence of natural feeding, besides the little space per fish, that do not follows the population density limits, which according to Coda (1996), have great influence on the growth index of the fishes.

Physical-chemist Analysis of the Water in the Amianthus Boxes

The average values obtained for the physical-chemical variables are in the zone considered ideal for fish breeding, according to Tavares (1994). The rate of water change was kept high during the experimental period, so that the values obtained for the physical-chemical variables of the water did not represent significant statistic difference $(\mathrm{P}<0,05)$ among the treatments $\mathrm{T}_{1}, \mathrm{~T}_{2}$, $\mathrm{T}_{3}$ and $\mathrm{T}_{4}$.

The Tukey's test for the average of the physical-chemical analysis of the water in each treatment are on Table 3.

The most important variables that must be controlled in fish breeding, after Boyd (1990), are: temperature, alkalinity, dissolved oxygen, ammonia, nitrite, phosphorus and $\mathrm{pH}$. 
TABLE 2

Length and average weigh of fishes on treatments $T_{1}, T_{2}, T_{3}$ and $T_{4}$.

\begin{tabular}{|l|c|c|c|c|c|c|c|c|}
\hline & \multicolumn{4}{|c}{ Length $(\mathbf{c m})$} & \multicolumn{4}{c|}{ Weight $(\mathbf{g})$} \\
\hline Months & $\mathbf{T}_{\mathbf{1}}=\mathbf{0}$ & $\mathbf{T}_{\mathbf{2}}=\mathbf{1 0}$ & $\mathbf{T}_{\mathbf{3}}=\mathbf{2 0}$ & $\mathbf{T}_{\mathbf{4}}=\mathbf{3 0}$ & $\mathbf{T}_{\mathbf{1}}=\mathbf{0}$ & $\mathbf{T}_{\mathbf{2}}=\mathbf{1 0}$ & $\mathbf{T}_{\mathbf{3}}=\mathbf{2 0}$ & $\mathbf{T}_{\mathbf{4}}=\mathbf{3 0}$ \\
\hline 0 & 3.75 & 3.75 & 3.73 & 3.93 & 1.29 & 1.31 & 1.16 & 1.36 \\
\hline 1 & 5.43 & 5.61 & 5.88 & 6.39 & 3.45 & 4.32 & 4.15 & 5.05 \\
\hline 2 & 6.25 & 6.57 & 7.02 & 8.038 & 5.98 & 7.91 & 7.37 & 10.68 \\
\hline 3 & 6.94 & 7.64 & 7.46 & 8.86 & 7.92 & 11.14 & 9.14 & 14.08 \\
\hline 4 & 7.81 & 8.56 & 8.66 & 9.91 & 11.29 & 15.42 & 13.56 & 19.85 \\
\hline 5 & 9.141 & 9.83 & 9.74 & 11.05 & 17.41 & 22.71 & 19.43 & 27.32 \\
\hline 6 & 10.67 & 11.12 & 11.11 & 12.33 & 30.14 & 36.03 & 31.90 & 43.86 \\
\hline 7 & 11.78 & 12.13 & 12.30 & 13.18 & 44.10 & 49.15 & 45.17 & 57.06 \\
\hline 8 & 13.38 & 13.36 & 13.70 & 14.60 & 64.60 & 69.84 & 68.13 & 79.16 \\
\hline 9 & 15.23 & 14.40 & 15.56 & 15.86 & 90.19 & 81.37 & 99.28 & 102.32 \\
\hline 10 & 17.22 & 16.65 & 17.09 & 17.61 & 116.75 & 113.75 & 115.75 & 122.43 \\
\hline 11 & 18.28 & 17.40 & 18.09 & 18.69 & 154.18 & 139.35 & 151.29 & 161.65 \\
\hline
\end{tabular}

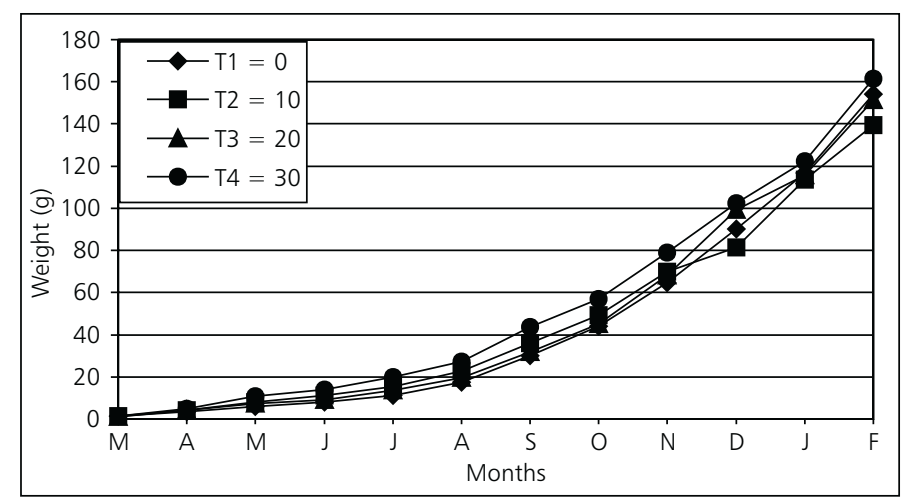

Fig. 1 - Average weight of the fishes (g).

TABLE 3

Tukey's test for the average of the physical-chemist analysis of the water.

\begin{tabular}{|l|c|c|c|c|}
\hline & \multicolumn{4}{|c|}{ \% of yeast in the amianthus boxes } \\
\hline Variables & $\mathbf{T}_{\mathbf{1}}=\mathbf{0}$ & $\mathbf{T}_{\mathbf{2}}=\mathbf{1 0}$ & $\mathbf{T}_{\mathbf{3}}=\mathbf{2 0}$ & $\mathbf{T}_{\mathbf{4}}=\mathbf{3 0}$ \\
\hline Temperature $\left({ }^{\circ} \mathrm{C}\right)$ & 22.2900 & 22.2900 & 22.2900 & 22.2900 \\
\hline Alkalinity $\left(\mathrm{mgCaCO}_{3} / \mathrm{L}\right)$ & 759.5800 & 747.9200 & 730.6700 & 759.8300 \\
\hline Dissolved $\mathrm{O}_{2}(\mathrm{mg} / \mathrm{L})$ & 6.9720 & 6.7080 & 6.6880 & 6.7040 \\
\hline Ammonia $(\mathrm{mg} / \mathrm{L})$ & 0.0375 & 0.0304 & 0.0332 & 0.0430 \\
\hline Nitrite $(\mathrm{mg} / \mathrm{L})$ & 0.0136 & 0.0125 & 0.0114 & 0.0108 \\
\hline Total Phosphorus $(\mathrm{mg} / \mathrm{L})$ & 0.0433 & 0.0433 & 0.0433 & 0.0433 \\
\hline Dissolvable phosphorus $(\mathrm{mg} / \mathrm{L})$ & 0.0294 & 0.0294 & 0.0294 & 0.0294 \\
\hline $\mathrm{pH}$ & 6.3870 & 6.3850 & 6.8560 & 6.7380 \\
\hline
\end{tabular}


The Table 4 presents the results of the cubic regression of the weight related to the months of the biometrics.

On Table 4, the high values for the determination coefficient $\left(\mathrm{r}^{2}\right)$ shows a perfect adjust of the studied variables to the mathematical model used. On the other side, the variation coefficient values (CV) lower than 10\% characterize homogeneity of the results, representative average and optimum experiment. These results showed the possibility of using up to $30 \%$ of distillery yeast in the tilapias ration without influence in its growth.

TABLE 4

Cubic regression between the weight $(y)$ and the time $(x)$ in months in the amianthus boxes.

\begin{tabular}{|l|l|c|c|}
\hline \% Yeast & Cubic regression & $\mathbf{r}^{2}$ & $\mathbf{C V}$ \\
\hline $\mathrm{T}_{1}=0$ & $\mathrm{y}=-2.29+0.52 \mathrm{x}+0.06 \mathrm{x}^{2}+0.10 \mathrm{x}^{3}$ & 0.9994 & 3.125 \\
$\mathrm{~T}_{2}=10$ & $\mathrm{y}=-2.12+1.28 \mathrm{x}+0.34 \mathrm{x}^{2}+0.06 \mathrm{x}^{3}$ & 0.9975 & 5.889 \\
$\mathrm{~T}_{3}=20$ & $\mathrm{y}=-3.17-0.16 \mathrm{x}+0.53 \mathrm{x}^{2}+0.09 \mathrm{x}^{3}$ & 0.9956 & 8.291 \\
$\mathrm{~T}_{4}=30$ & $\mathrm{y}=2.13+2.79 \mathrm{x}+0.28 \mathrm{x}^{2}+0.07 \mathrm{x}^{3}$ & 0.9981 & 4.965 \\
\hline
\end{tabular}

\section{Weight/length relation}

The constant value related to the growth form of the fish bodies (q) was near to 3,0. After Wootton (1990), the value $\mathrm{q}=3,0$ indicates a isometric growth. A value higher than 3,0 means that the fish became lighter on account to its growth in length. A value lower than 3,0 indicates that the fish became heavier because of the weight increase. Values close to these were found by Mainardes Pinto (1989), who worked with tilapias (O. niloticus) growth.

The condition factor (f) is very used in studies of fishery biology, indicating the well being degree of the fishes in the environment they live to verify if they make good use of the ration (Weatherley \& Gill, 1987).

The mathematical expressions of the curves of Weight/Total Length, Bodies Height/Total Length, Standard Length/Total Length and Barrel Length/Total Length of tilapias and the linear transformation correspondent to the treatments $\mathrm{T}_{1}$, $\mathrm{T}_{2}, \mathrm{~T}_{3}$ and $\mathrm{T}_{4}$ are on Table 5 .

The estimated values of the coefficient of linear correlation of Pearson are positive and near to 1 (one), which indicates the high association degree among the variables of the logarithmic expressions, proving analytically the validity of the adjustment expressions corroborating with the little dispersion observed of the empiric points to the theoretic curves.

\section{Growth curve of length and weight}

In this article, as there were no possibility to calculate the growth curves of length and weight of the fishes in the amianthus box by the expression of Von Bertalanffy (1938), because there were no satisfactory adjust to the experiments information. So it was choosed the experimental model described by Ricker (1979); Weatherley \& Gill (1987); Melo (1993), see Table 6.

The mathematical expressions used in the study of length growth were obtained from the exponential model of curve of weight growth.

\section{Biomass and production curves}

The mathematical expressions obtained through the exponential model for biomass and production are presented on Table 7 .

Although fishery is a millenary activity, the scientific studies to control and intensify the production in biomass is relatively recent. The study of the aquatic growing intend to explore more rationally the aquiculture, on account to obtain information about a higher or lower productivity of the species bred in the same environmental conditions, the optimum number of fish stocked and maximize the biomass in short time (Melo, 1993).

The expression of the curve of biomass and production were determined with knowledge of the mathematical expression of the curve of growth in weight and the survival rate. 
TABLE 5

The mathematical expressions of the graphics Weight/Total Length, Bodies Height/Total Length, Standard Length/Total Length and Barrel Length/Total Length of tilapias and the linear transformation correspondent to the treatments $T_{1}, T_{2}, T_{3}$ and $T_{4}$.

\begin{tabular}{|c|c|c|c|}
\hline \multicolumn{4}{|c|}{ Total Weight/Total Length } \\
\hline$\%$ Yeast & $\mathbf{W t}=\phi \mathbf{L} \mathbf{t}^{\theta}$ & $\ln \mathbf{W t}=\ln \phi+\theta \ln \mathbf{L t}$ & $\mathbf{r}_{\mathrm{xy}}$ \\
\hline $\mathrm{T}_{1}=0$ & $\mathrm{Wt}=0.02143 \mathrm{Lt}^{3.05}$ & $\ln \mathrm{Wt}=-3.8429+3.05 \operatorname{lnLt}$ & 0.9842 \\
\hline $\mathrm{T}_{2}=10$ & $\mathrm{Wt}=0.02318 \mathrm{Lt}^{3.05}$ & $\ln \mathrm{Wt}=-3.7645+3.05 \operatorname{lnLt}$ & 0.9842 \\
\hline $\mathrm{T}_{3}=20$ & $\mathrm{Wt}=0.01695 \mathrm{Lt}^{3.13}$ & $\ln \mathrm{Wt}=-4.0775+3.13 \operatorname{lnLt}$ & 0.9842 \\
\hline $\mathrm{T}_{4}=30$ & $\mathrm{Wt}=0.01563 \mathrm{Lt}^{3.15}$ & $\ln \mathrm{Wt}=-4.1586+3.15 \ln \mathrm{Lt}$ & 0.9842 \\
\hline \multicolumn{4}{|c|}{ Bodies Height/Total Length } \\
\hline$\%$ Yeast & $\mathbf{H c o}=\phi \mathbf{L} \mathbf{t}^{\theta}$ & $\ln \mathbf{H c o}=\ln \phi+\theta \operatorname{lnLt}$ & $\mathbf{r}_{\mathrm{xy}}$ \\
\hline $\mathrm{T}_{1}=0$ & $\mathrm{Hco}=0.25347 \mathrm{Lt}^{1.12}$ & $\ln \mathrm{Hco}=-1.3728+1.12 \operatorname{lnLt}$ & 0.9997 \\
\hline $\mathrm{T}_{2}=10$ & $\mathrm{Hco}=0.25315 \mathrm{Lt}^{1.13}$ & $\ln \mathrm{Hco}=-1.3738+1.13 \operatorname{lnLt}$ & 0.9996 \\
\hline $\mathrm{T}_{3}=20$ & $\mathrm{Hco}=0.25905 \mathrm{Lt}^{1.10}$ & $\ln \mathrm{Hco}=-1.3507+1.10 \operatorname{lnLt}$ & 0.9999 \\
\hline $\mathrm{T}_{4}=30$ & $\mathrm{Hco}=0.24606 \mathrm{Lt}^{1.12}$ & $\ln \mathrm{Hco}=-1.4022+1.12 \operatorname{lnLt}$ & 0.9968 \\
\hline \multicolumn{4}{|c|}{ Standard Length/Total Length } \\
\hline$\%$ Yeast & $\mathbf{L p}=\phi \mathbf{L} \mathbf{t}^{\theta}$ & $\ln \mathbf{L p}=\ln \phi+\theta \ln \mathbf{L t}$ & $\mathbf{r}_{\mathrm{xy}}$ \\
\hline $\mathrm{T}_{1}=0$ & $\mathrm{Lp}=0.78625 \mathrm{Lt}^{1.00}$ & $\ln L p=-0.2405+1.00 \ln L t$ & 1.0000 \\
\hline $\mathrm{T}_{2}=10$ & $\mathrm{Lp}=0.75406 \mathrm{Lt}^{1.02}$ & $\ln \mathrm{Lp}=-0.2823+1.02 \operatorname{lnLt}$ & 1.0000 \\
\hline $\mathrm{T}_{3}=20$ & $\mathrm{Lp}=0.76975 \mathrm{Lt}^{1.01}$ & $\ln \mathrm{Lp}=-0.2617+1.01 \mathrm{lnLt}$ & 1.0000 \\
\hline $\mathrm{T}_{4}=30$ & $\mathrm{Lp}=0.78588 \mathrm{Lt}^{1.00}$ & $\ln \mathrm{Lp}=-0.2500+1.00 \ln \mathrm{Lt}$ & 1.0000 \\
\hline \multicolumn{4}{|c|}{ Barrel Length/Total Length } \\
\hline$\%$ Yeast & $\mathbf{L t r}=\phi \mathbf{L t}^{\theta}$ & $\ln \mathbf{L t r}=\ln \phi+\theta \ln \mathbf{L t}$ & $\mathbf{r}_{\mathrm{xy}}$ \\
\hline $\mathrm{T}_{1}=0$ & $\mathrm{Ltr}=0.45610 \mathrm{Lt}^{1.09}$ & $\ln \mathrm{Ltr}=-0.7850+1.09 \ln \mathrm{Lt}$ & 0.9998 \\
\hline $\mathrm{T}_{2}=10$ & $\mathrm{Ltr}=0.47875 \mathrm{Lt}^{1.06}$ & $\ln \mathrm{Ltr}=-0.7366+1.06 \operatorname{lnLt}$ & 1.0000 \\
\hline $\mathrm{T}_{3}=20$ & $\mathrm{Ltr}=0.51578 \mathrm{Lt}^{1.03}$ & $\ln \mathrm{Ltr}=-0.6621+1.03 \operatorname{lnLt}$ & 1.0000 \\
\hline $\mathrm{T}_{4}=30$ & $\mathrm{Ltr}=0.51649 \mathrm{Lt}^{1.04}$ & $\ln \mathrm{Ltr}=-0.6607+1.04 \operatorname{lnLt}$ & 0.9999 \\
\hline
\end{tabular}

$\mathrm{Wt}=$ Weight Lt $=$ Total Length; Hco = Bodies Height; $\mathrm{Lp}=$ Standard Length; Ltr = Barrel Length; and $\mathrm{r}_{\mathrm{xy}}$ is the linear coefficient of Pearson.

\section{TABLE 6}

Mathematical expressions obtained through the exponential growth in length and weight of tilapias in the treatments $T_{1}, T_{2}, T_{3}$ and $T_{4}$.

\begin{tabular}{|l|c|c|}
\hline \% Yeast & $\mathbf{L t}=\mathbf{L o} \mathrm{e}^{\mathbf{g t} / \theta}$ & $\mathbf{r}_{\mathbf{x y}}$ \\
\hline $\mathrm{T}_{1}=0$ & $\mathrm{Lt}=3.75 \mathrm{e}^{0.14211 \mathrm{t}}$ & 1.0000 \\
\hline $\mathrm{T}_{2}=10$ & $\mathrm{Lt}=3.75 \mathrm{e}^{0.13910 \mathrm{t}}$ & 1.0000 \\
\hline $\mathrm{T}_{3}=20$ & $\mathrm{Lt}=3.73 \mathrm{e}^{0.14147 \mathrm{t}}$ & 1.0000 \\
\hline $\mathrm{T}_{4}=30$ & $\mathrm{Lt}=3.93 \mathrm{e}^{0.13789 \mathrm{t}}$ & 1.0000 \\
\hline \% Levedura & $\mathbf{W t}=\mathbf{W o ~ e}^{\mathbf{g t}}$ & $\mathbf{r}_{\mathbf{x y}}$ \\
\hline $\mathrm{T}_{1}=0$ & $\mathrm{Wt}=1.29 \mathrm{e}^{0.43486 \mathrm{t}}$ & 1.0000 \\
\hline $\mathrm{T}_{2}=10$ & $\mathrm{Wt}=1.31 \mathrm{e}^{0.42427 \mathrm{t}}$ & 1.0000 \\
\hline $\mathrm{T}_{3}=20$ & $\mathrm{Wt}=1.16 \mathrm{e}^{0.44280 \mathrm{t}}$ & 1.0000 \\
\hline $\mathrm{T}_{4}=30$ & $\mathrm{Wt}=1.36 \mathrm{e}^{0.43436 \mathrm{t}}$ & 1.0000 \\
\hline
\end{tabular}

Lo = Initial Length; Wo = Initial Weigt; and $x y$ is the coefficient of linear correlation of Pearson. 
TABLE 7

Mathematical expressions obtained through the exponential model for biomass and production of tilapias in the treatments $T_{1}, T_{2}, T_{3}$ and $T_{4}$.

\begin{tabular}{|c|c|c|}
\hline & Biomass & \\
\hline$\%$ Yeast & $B t=10^{-3} N_{0} S_{t}$ Wo e $e^{g t} \quad(k g)$ & $\mathbf{r}_{\mathbf{x y}}$ \\
\hline $\mathrm{T}_{1}=0$ & $\mathrm{Bt}=10^{-3} \mathrm{NoS}_{\mathrm{t}}(1.29) \mathrm{e}^{0.43486 \mathrm{t}}$ & 0.9997 \\
\hline $\mathrm{T}_{2}=10$ & $\mathrm{Bt}=10^{-3} \operatorname{NoS}_{\mathrm{t}}(1.31) \mathrm{e}^{0.42427 \mathrm{t}}$ & 0.9998 \\
\hline $\mathrm{T}_{3}=20$ & $\mathrm{Bt}=10^{-3} \operatorname{NoS}_{\mathrm{t}}(1.16) \mathrm{e}^{0.44280 \mathrm{t}}$ & 0.9999 \\
\hline \multirow[t]{2}{*}{$\mathrm{T}_{4}=30$} & $\mathrm{Bt}=10^{-3} \mathrm{NoS}_{\mathrm{t}}(1.36) \mathrm{e}^{0.43436 \mathrm{t}}$ & 0.9990 \\
\hline & Produção & \\
\hline$\%$ Yeast & $P t=10^{-3}$ No Wo $e^{g t} \quad(k g)$ & $\mathbf{r}_{\mathrm{xy}}$ \\
\hline $\mathrm{T}_{1}=0$ & $\mathrm{Pt}=10^{-3} \mathrm{No}(1.29) \mathrm{e}^{0.43486 \mathrm{t}}$ & 1.0000 \\
\hline $\mathrm{T}_{2}=10$ & $\mathrm{Pt}=10^{-3} \mathrm{No}(1.31) \mathrm{e}^{0.42427 \mathrm{t}}$ & 1.0000 \\
\hline $\mathrm{T}_{3}=20$ & $\mathrm{Pt}=10^{-3} \mathrm{No}(1.16) \mathrm{e}^{0.44280 \mathrm{t}}$ & 1.0000 \\
\hline $\mathrm{T}_{4}=30$ & $\mathrm{Pt}=10^{-3} \mathrm{No}(1.36) \mathrm{e}^{0.43436 \mathrm{t}}$ & 1.0000 \\
\hline
\end{tabular}

$\mathrm{Bt}=$ Biomass; $\mathrm{Pt}=$ Produc ion; and $\mathrm{r}_{\mathrm{xy}}$ is the coefficient of linear correlation of Pearson.

\section{Contribution of the experimental rations in the studied parameters}

The analysis of the final results of the experiment (Table 8) show that the final length, the daily increase of length and weight, feed conversion coefficient, efficiency and survival did not present significant statistic differences $(\mathrm{P}<0.05)$ among the treatments.

Although the final weight did not present significant statistic differences $(\mathrm{P}<0.05)$ among the treatments, the treatment with $\mathrm{T}_{4}=30 \%$ of distillery yeast presented the highest average.

The final biomass of the fishes presented significant differences $(\mathrm{P}<0.05)$ among the treatments, being $\mathrm{T}_{1}$ and $\mathrm{T}_{4}$ higher than $\mathrm{T}_{2}$ and $\mathrm{T}_{3}$.

The highest increase of absolute weight was $160,3 \mathrm{~g}$ in treatment $\mathrm{T}_{4}=30 \%$, statistically higher $(\mathrm{P}<0.01)$ than the others treatments $\mathrm{T}_{1}=0 \%, \mathrm{~T}_{2}=$ $10 \%$ and $\mathrm{T}_{3}=20 \%$, which did not present differences from each other.

The highest increase of relative weight was $12942 \mathrm{~g}$ in treatment $\mathrm{T}_{3}$, statistically higher $(\mathrm{P}<$ $0.01)$ than $\mathrm{T}_{1}(11,852 \mathrm{~g})$ and $\mathrm{T}_{4}(11,787 \mathrm{~g})$, which did not differ from each other, but were higher than the treatment $\mathrm{T}_{2}(10,537 \mathrm{~g})$.

Averages followed by distinct capital letters differ from each other at $5 \%$ of probability level (P $<0.05$ ) and the ones followed by distinct small letters differ from each other at $1 \%$ of probability level $(\mathrm{P}<0.01)$
The yield of the inclusion of distillery yeast (Saccharomyces cerevisiae) in balanced experimental rations related to the development of the fishes did not show damage effect until the maximum level tested of $30 \%$, which shows that the choice of yeast level in rations for fish breeding depends only of its availability and occasional cost.

The feed efficiency (Ea) is the inverse of the feed conversion (S), which means increase of weight/ food consumed (Chiu, 1989). Efficiency refers to the ability of the animal to convert the feed consumed in eatable products or others products (Webb, 1978; Devendra, 1989). The reduction on the growth rate was followed by an increase in the feed efficiency.

Some author cited in literature, who worked with distillery yeast in fish breeding, came to these conclusions:

Ribeiro et al. (1996), who worked with Nile tilapia objecting to analyze the availability of the inclusion of increasing levels of sugarcane yeast, $(18 \%, 36 \%, 54 \%, 72 \%, 90 \%)$ included in the ratons in a period of 45 days.

Pezzato et al. (1982), cited by Castagnolli (1992), substituted gradually meat flour by dry yeast at levels of $\mathrm{A}=0 \%, \mathrm{~B}=33.3 \%, \mathrm{C}=66.6 \%$ and $\mathrm{D}=100 \%$ and concluded that the treatments that received yeast were superior to the testimony and that the substitution of $33.3 \%$ of yeast was statistically the one that propitiated the best result. 
TABLE 8

Turkey test for individual length (Lf), increase of weight (Wf), biomass (Bf), increase of absolute (Gpa) and relative (Gpr) weight, daily increase of length(ILd) and weight (IWd), feed conversion coefficient (S), efficiency (Ea) and survival ( $\mathrm{Sb}$ ) at the end of the experimental period.

\begin{tabular}{|l|c|c|c|c|c|c|c|c|c|c|}
\hline \multicolumn{10}{|c|}{ Parameters } \\
\hline \% Yeast & Lf (cm) & Wf (g) & Bf $(\mathbf{k g})$ & Gpaf $(\mathbf{g})$ & Gprf (g) & ILdf $(\mathbf{c m})$ & IWdf (g) & Sf & Eaf & Sbf $(\%)$ \\
\hline $\mathrm{T}_{1}=0$ & $18.28 \mathrm{~A}$ & $154.2 \mathrm{~A}$ & $6.476 \mathrm{a}$ & $152.9 \mathrm{~b}$ & $11852 \mathrm{~b}$ & $0.044 \mathrm{~A}$ & $0.463 \mathrm{~A}$ & $3.734 \mathrm{~A}$ & $0.268 \mathrm{~A}$ & $70.00 \mathrm{~A}$ \\
\hline $\mathrm{T}_{2}=10$ & $17.40 \mathrm{~A}$ & $139.4 \mathrm{~A}$ & $5.471 \mathrm{~b}$ & $138.0 \mathrm{~b}$ & $10537 \mathrm{c}$ & $0.041 \mathrm{~A}$ & $0.418 \mathrm{~A}$ & $4.345 \mathrm{~A}$ & $0.230 \mathrm{~A}$ & $68.33 \mathrm{~A}$ \\
\hline $\mathrm{T}_{3}=20$ & $18.09 \mathrm{~A}$ & $151.3 \mathrm{~A}$ & $6.203 \mathrm{~b}$ & $150.1 \mathrm{~b}$ & $12942 \mathrm{a}$ & $0.044 \mathrm{~A}$ & $0.455 \mathrm{~A}$ & $3.989 \mathrm{~A}$ & $0.251 \mathrm{~A}$ & $73.33 \mathrm{~A}$ \\
\hline $\mathrm{T}_{4}=30$ & $18.69 \mathrm{~A}$ & $161.7 \mathrm{~A}$ & $7.113 \mathrm{a}$ & $160.3 \mathrm{a}$ & $11787 \mathrm{~b}$ & $0.045 \mathrm{~A}$ & $0.486 \mathrm{~A}$ & $4.264 \mathrm{~A}$ & $0.235 \mathrm{~A}$ & $73.33 \mathrm{~A}$ \\
\hline
\end{tabular}

Averages followed by distinct capital letters differ from each other at $5 \%$ of probability level $(\mathrm{P}<0,05)$ and the ones followed by distinct small letters differ from each other at $1 \%$ of probability level $(\mathrm{P}<0.01)$.

For Alves et al. (1988) the optimum level of substitution of soybean flour by yeast (Saccharomyces cerevisiae) for an increase of weight in Nile tilapias were $36.97 \%$. The results obtained are according to Cowey (1974), when compared the nutritional worth of the yeast, and Matty et al. (1978), who attributed to the yeast the digestibility the proteic matter closed to the observed with soybean flour and that rates higher than $40 \%$ of yeast decrease the development of trout.

Pádua (1996), tested five levels $(0 \%, 25 \%$, $50 \%, 75 \%$ and $100 \%$ ) of substitution of dry fish flour by distillery yeast as proteic supplement and observed that until levels of $75 \%$ of substitution did not show damage effect in the productive development and in the metabolism of young pacu.

After Roberts et al. (1988), deficient proteic supply determine a limited growth of the fishes, which can cause some symptoms such as erosion in the dorsal flipper, abnormalities in the vertebral column and darkening of the skin. Waagbo (1994) commented the importance of nutrients in diet on general metabolism and on the animal immunity, suggesting that a good knowledge of preparation of the feed improve the conditions in the breeding, reducing the losses by death.

\section{REFERENCES}

AlVES, L. M. C. G., PEZZATO, L. E., NETO, A. C. G., PEZZATO, A. C., BARROS, M. M. \& PADOVANI, C. R., 1988, Avaliação de níveis crescentes de levedura seca de vinhaça incorporadas às rações de tilápia do Nilo. In: Simpósio Latinoamericano de Aqüicultura, 6. Simpósio Brasileiro de Aqüicultura, 5, Florianópolis, Resumos, Florianópolis, Abraq, 355-361.
BERTALANFFY, L. von., 1938, A quantitative theory of organic grouth. Hum. Biol., 10(2): 181-213.

BOYD, C. E., 1990, Water quality in ponds for aquaculture. Birmingham: Alabama Agricultural Experiment Station, $477 \mathrm{p}$.

CARNEIRO, W., 1971, Comentário Econômico: proteínas. Brasil Açucareiro, Rio de Janeiro, 77(6): 15-16.

CAStagnOLli, N., 1992, Piscicultura de água doce. FUNEP, Jaboticabal, 189p.

CHIU, Y., 1989, Considerations for feeding experiments to quantify dietary requirements of essential nutrients in fish In: S. S. da Silva (ed.), Fish nutrition research in Asia. Manila: Asian Fisheries Society, pp. 46-59.

CODA, S., 1996, Efeito da densidade de estocagem no cultivo intensivo de tilápia do Nilo, Oreochromis niloticus. In: Simpósio Brasileiro de Aqüicultura, 9, Sete Lagoas, Mg. p.131. Resumos. Sete Lagoas, Simbraq.

COWEY, C. B., 1974, Studies on the nutricion of marine Flat-fish. The effect of dietary protein content on certain cell components and enzymes in the liver of Pleuronects platessa. MARS. BIOL, 28: $207-$ 213.

DEVENDRA, C., 1989, Nomenclature, terminology and definitions appropriate to animal nutrition. In: S. S. da Silva (ed.), Fish nutrition research in Asia. Manila: Asian Fishery Society, pp. 1-10. (Asian Fish. Soc. Publ. n. 4.)

IVLEV, V. S., 1966, The biological productivity of waters. J. Fish Res. Board. Can., 23(11): 1727-59.

LIND, O. T., 1979, Handbook of common methods in limnology. London, ed. Mosby, pp. 59-85.

MAINARDES PINTO, C. S. R., 1989, Criação de tilápia. Instituto de Pesca, São Paulo, 13p. (Boletim Técnico, 10).

MATTOS, W. R. S., DANTAS D'ARCE, R. \& MACHADO, P. F., 1984, O uso de levedura da fermentação alcoólica na alimentação de ruminantes. Informe Agropecuário, Belo horizonte, 10(119): 5660 . 
MATTY, A. J., SMITH, P., 1978, Evaluation of a yeast, bacterium and alga as protein source for rainbowtrout. 1. Effect of protein level on growth, gross convertion efficiency and protein conversion efficiency. EIFAC/78/SYMP., E/7.

MEDRI, V., 1997, Técnicas estatísticas e de engenharia da qualidade para avaliar o desempenho de diferentes níveis de levedura na criação de tilápia (Oreochromis niloticus). Tese de Doutorado em Engenharia de Produção, Universidade Federal de Santa Catarina, Florianópolis, $180 \mathrm{p}$.

MELO, J. S. C., 1993, Aspectos quantitativos do crescimento do Híbrido Tambacu (fêmea de Colossoma Macropomum $x$ macho de Piaractus Mesopotamicus) sob condições de criação intensiva. Dissertação de Mestrado em Aqüicultura, Universidade Federal de Santa Catarina, Florianópolis, 56p.

NETO, A. C. G., SILVEIRA, A., PEZZATO, L. E., BARROS, M. M. \& PADOVANI, C. R., 1988, Subproduto da indústria de gelatina como sucedâneo protéico na alimentação da tilápia do Nilo. In: Simpósio Latinoamericano de Aqüicultura, 6. Simpósio Brasileiro de Aqüicultura, 5, Florianópolis, SC. Resumos. Florianópolis, Abraq.

PÁDUA, D. M. C., 1996, Utilização da levedura alcoólica (Saccharomyces cerevisiae) como fonte protéica na alimentação de juvenis de pacu (Piaractus mesopotamicus, PISCES, TELEOSTEI): aspectos metabólicos e de desempenho produtivo. Dissertação de Mestrado, Universidade Estadual Paulista, Jaboticabal, 120p.

RIBEIRO R. P., HAYASHI, C., FURUYA, W. M., FURUYA, V. R. B. \& SOARES, C. M., 1996, Utilização de diferentes níveis de levedura seca, Saccharomyces cerevisiae, em dietas para alevino de tilápias do Nilo, Oreochomis niloticus, em cultivo monossexo. In: Simpósio Brasileiro de Aqüicultura, 9, Sete Lagoas, p. 99. Resumos. Sete Lagoas, Simbraq.

RICKER, W. E., 1979, Growth rates and models. In: W. S. Hoar, D. J. Randall \& J. R. Brett (eds.), Fish Physiology. Academic Press, New York, 81: 677-743.
ROBERTS, R. J. \& BULLOCK, A. M., 1988, Nutritional pathology. In: J. E. Halver, Fish Nutrition. Academic Press, New York, pp. 424-469.

SANTOS, E. P., 1978, Dinâmica de populações aplicada à pesca e piscicultura. ed. Univ. São Paulo, Hucitec. $129 \mathrm{p}$.

STANDARD METHODS, 1980, For the examination of water and wastewater. 15 ed APHA- AWWA-WPCF 1 , pp. 380-491.

SWINGLE, H. S., 1961, Relationship of $\mathrm{pH}$ of pond waters to their suitability for fish culture. Fisheries, 10: 72-75. (Proceeding Pacific Science Congress, 9, 1957.)

TAVARES, L. H. S., 1994, Limnologia aplicada à aqüicultura. FUNEP, Jaboticabal, pp. 14-37.

WAAGBO, R., 1994, The impact of nutritional factors on the immune system in Atlantic salmon, salmo solar. Aquacult Fish Manag., Oxford, 25(2): 175-197.

WEATHERLEY, A. H. \& GILL, H. S., 1987, The biology of fish growth. Academic Press, London, 443p.

WEBB, P. W., 1978, Partitioning of energy into metabolism and growth. In: S. D. Gerking (ed.), Ecology of Freshwater Fish Production. Blackwell Scientific Publications, Oxford, pp. 184-214.

WILSON, R. P. (ed.), 1991, Handbook of nutrient requirements of finfish. Boca Raton, CRC, p. 176.

WOOTTON, R. J., 1990, Ecology of teleosts fishes. Chapman and Hall, London, 404p.

WU, V. Y., ROSATI, R. R., SESSA, D. J. \& BROWN, P. B., 1995b, Evaluation of corn gluten meal as a protein source in tilapia diets. J. Agric. Food Chem., 43: 1585-88. 